\title{
PRESERVING DUTCH FASHION ARCHIVES. THE FASHION NETWORK ARNHEM ${ }^{1}$
}

\author{
Preservação dos Arquivos Holandeses de Moda. \\ A Rede de Moda Arnhem
}

\author{
Fred van Kan*
}

\begin{abstract}
In 2011 the Museum of Modern Art Arnhem, ArtEz Institute of the Arts and the Gelders Archives have joint forces to preserve the archives of modern Dutch fashion. They established the Modekern, a network in which each partner has its own responsibility. The Gelders Archives archives the records of important Dutch fashion designers, including sketches, fabric samples experiments and portfolios. The fashion academy of ArtEz uses these records for research and education. Designers and students can study these fashion archives, become inspired and use it for their own development. The Museum organizes exhibitions based on the archives and using fashion objects. No new institute was founded, but in this collaboration each partner brings in its strength: the whole is more than the sum of its parts. In this article attention is paid to the development of the Modekern 2011-2017.
\end{abstract}

Keywords: dutch fashion; Modekern; fashion archives

\section{RESUMO}

Em 2011, o Museu de Arte Moderna de Arnhem, o Instituto de Artes ArtEz e o Arquivo de Gelders uniram forças para preservar os arquivos da moda holandesa moderna. Eles estabeleceram o Modekern, uma rede na qual cada parceiro tem uma responsabilidade especial. $\mathrm{O}$ Arquivo de Gelders reúne os

1 This article is an adaptation of a lecture given on 13/10/2014 at the 2nd Annual Conference of the International Council on Archives, Girona, Catalonia.

* Gelders Archives, The Netherlands 
registros de importantes designers de moda holandeses, incluindo esboços, experimentos com tecido e portfólios. A academia de moda da ArtEz usa esses registros para pesquisa e educação. Designers e estudantes podem examniar esses arquivos de moda, se inspirar e usá-los para o seu próprio desenvolvimento. $\mathrm{O}$ Museu organiza exposições baseadas nos arquivos e no uso de objetos de moda. Nenhum novo instituto foi fundado, mas nesta colaboração cada parceiro traz sua força: o todo é mais do que a soma de suas partes. Neste artigo dedicamos atenção ao desenvolvimento do Modekern no peíodo 2011-2017.

Keywords: moda holandesa; Modekern; arquivos de moda

The Dutch Archives Law provides for the preservation of all public archives on the national, provincial, and local level. ${ }^{2}$ In addition, the corresponding archival institutions are permitted to acquire private archives ${ }^{3}$. Consequently, there is, in principle, a safety net to preserve all the archives of cultural and historical significance for posterity. In The Netherlands, there is a long-standing tradition for archives to acquire private collections that are related to their geographic area. For example, the Gelders Archives, where I work, houses the archives of sports clubs, churches, hospitals, charities, companies, etcetera. ${ }^{4}$ Although a safety net exists, unfortunately, valuable archives still get lost or are in danger of being lost. Among these threatened archives are the archives of designers, and more specifically those of fashion designers.

In 2001, a Temporary Advisory Committee on Design, established by the Ministry of Education, Culture, and Science, noted that nearly no attention was being paid to the conservation of design collections and archives, so they faced the risk of destruction and oblivion $^{5}$. As a result of this report a working group on design archives was established under the presidency of Premsela, the Netherlands Institute for Design and Fashion ${ }^{6}$. In 2005 this group

2 http://wetten.overheid.nl/BWBR0007376 (retrieved 17/02/2017).

3 ibidem, article 1 sub c 3.

4 www.geldersarchief.nl.

5 Advies Commissie Vormgeving 2001 (rapport van de Tijdelijke Adviescommissie Vormgeving).'s-Gravenhage, 2001, p. 13.

6 Merged in 2013 with other institutions in: HThet Nieuwe Instituut, national institute for architecture, design and e-culture. 
reported on design archives' situation, recommended registering all Dutch design archives and beginning to secure the archives of designers of national and international importance. ${ }^{7}$ Subsequently, in 2006, a master plan, the Heritage Design Archives, was drafted. This master plan was recommended rescuing the 'top 20' of most important and threatened archives and creating a central register on design archives. The Mondriaan Foundation, financed by the Dutch government, granted $€ 960.000$ for the implementation of the master plan. ${ }^{8}$ Consequently, from 2007-2010, twenty archives belonging to various disciplines of Dutch design, such as graphic design, industrial design, conceptual crafts, and fashion design, were made accessible and transferred to archives and museums. ${ }^{9}$

The grant also made it possible to develop an online database to map the design archives in $2008 .{ }^{10}$ Currently this database is populated and is called NOA, the National Design Archive. ${ }^{11}$ NOA lists the archives of nearly 2,000 Dutch designers, galleries, associations, agencies, and companies. The archives have been identified, but not all have been rescued. Without preservation and accessibility of the design archives themselves, it is impossible to study the history of Dutch design. These archives are essential for research, not only of design history in general, but also to reconstruct a specific design process.

What is true for design archives as a whole, also applies to fashion design. Until the 1960's fashion designers in the Netherlands copied the examples of the Paris' couturiers, but this changed in that period. Since then, talented designers followed their own ideas and original creativity evolved. Nowadays Dutch fashion design is internationally acclaimed, Viktor \& Rolf, for instance, is well-known,

7 TIMMER, Petra, Een toekomst voor vormgevingsarchieven. Achtergrond en analyse. Amsterdam: Premsela, 2005.

8 KNOOP, Riemer, Evaluatie Regeling Vormgevingsarchieven. Amsterdam: Gordion Cultureel Advies, 2010, p. 4.

9 KNOOP, Riemer, op. cit., pp. 8-10.

10 ibidem, pp. 4, 8-9.

11 http://www.nationaalontwerparchief.nl (retrieved 17/02/2017). 
and brands like G-star, Mexx, and Oilily are successful all over the world. $^{12}$

Unfortunately, there is no institute in the Netherlands where Dutch fashion is permanently exhibited. There are some museums that manage fashion collections, but it is not their priority to exhibit these collections. For fashion archives the situation is even worse. A first step to the preservation of fashion archives was a quick scan of the archives of five important designers: Frank Govers, Jan Janssen, Piet Paris, Alexander van Slobbe, and Viktor \& Rolf. This quick scan was financed by the Mondriaan Foundation in 2009 and $2010 .{ }^{13}$ It included a delineation of the importance of the designer, the historical context of the archives, a survey of the archives, a plan for the arranging and describing of the records, and an estimated budget.

Most of the important current Dutch fashion designers graduated in Arnhem, in the eastern part of The Netherlands, at the predecessor of the ArtEZ Institute of Arts. It is therefore understandable that José Teunissen, at the time a lecturer in fashion design at the ArtEZ, ${ }^{14}$ undertook an initiative to establish an institute for fashion heritage there. She advocated for such an institute not only to preserve the archives but also to facilitate research. In 2008, she was one of the initiators of the research project 'Dutch Fashion Identity in a Globalized World', ${ }^{15}$ a collaborative of the ArtEZ, the University of Amsterdam, and the Saxion University of Applied Sciences. Working on this project, she discovered that it is difficult to locate and consult the archives of designers. They are not interested in receiving students and other researchers time and again. Therefore, transfer of these archives to an archival institute would greatly facilitate research. In 2009 José Teunissen started a dialogue with the directors of the Arnhem Museum of Modern Art and the Gelders Archives on the issue of a fashion heritage institute. The Museum

12 VAN DER HORST, Annelies and DE GROOT, Marieke, Modekern Arnhem. Haalbaarheidsonderzoek. Amsterdam: DSP-groep, 2010, p. 8 and 22.

$13 \mathrm{http}: / /$ www.mondriaanfonds.nl/wp-content/uploads/2012/05/MS_jaarverslag_2009 pdf 131 (retrieved 17/02/2017).

14 Currently she is dean of the School of Design and Technology at London College of Fashion, UAL, and Professor of Fashion Theory.

15 See http://www.nwo.nl/onderzoek-en-resultaten/onderzoeksprojecten/i/82/3982.html (retrieved 17-02-2017). 
organized exhibitions on fashion in 2005, 2007 and 2009. Since it is part of the policy of this museum to pay attention to the disciplines of design and especially fashion design, ${ }^{16}$ the museum was interested in cooperating and collaborating.

The Gelders Archives is a Regional History Center. These Centers exist in most Dutch provinces and are a merger of the municipal archives in the provincial capital with the provincial archives. In Arnhem, the archives of neighbouring municipalities are also included. Governmental records of enduring value are transferred to these Centers, but private archives are also acquired. The Gelders Archives aims at a balanced and representative collection; that means a collection that reflects themes specific to Gelderland and the Arnhem region, including fashion design. ${ }^{17}$ The Gelders Archives already housed important collections for historical research on fashion, such as the one of fashion photographer René Brachten and some magazines. Furthermore, information could be found on clothing, costumes, and uniforms in past centuries in some of the private archives. Consequently, the Gelders Archives was also interested in collaborating in this project.

The initiative of the ArtEZ lecturer resulted in the establishment in 2011 of the Modekern Foundation, Institute for Fashion Heritage. The focus of this foundation is to collect, provide access to, study, and exhibit the archives of internationally significant Dutch fashion designers. The board of the Modekern Foundation consists of the lecturer on fashion design at the ArtEZ and the directors of the Museum and the Archives. The foundation functions as a networked group. This means that there is no new building but that each partner brings its strength to the organization and has its own responsibility. The Gelders Archives manages the records of important fashion designers and the ArtEZ uses these records for research and education. Designers and students can study these

16 MUSEUM VOOR MODERNE KUNST ARNHEM, Jaarverslag 2008-2009. Arnhem: MMKA, 2009, p. 6.

17 See for the current ideas on acquisition of private archives in The Netherlands: JEURGENS, K.J.P.F.M., BONGENAAR, A.C.V.M. and WINDHORST, M.C., Gewaardeerd verleden. Bouwstenen voor een nieuwe waarderingsmethodiek voor archieven. 's-Gravenhage: Nationaal Archief, 2007, pp. 36-39. 
fashion archives, become inspired and use the material for their own development. The Museum organizes exhibitions based on the archives and fashion objects. Together the three partners take care of the Modekern website.

Premsela, the Netherlands Institute for Design and Fashion, with a responsibility to promote the preservation of design, welcomed the Modekern initiative. Because of the establishment of the Modekern, a category of design that had not yet been collected would have a safe haven. This institute offered the Modekern a project coordinator until December 2013.

The city of Arnhem and the province of Gelderland subsidized the Modekern from 2011-2013 to the sum of $€ 290.000$. For the municipality and the province, the initiative fitted very well with the policy of both governments to stimulate fashion and fashion design in Arnhem for economic as well as cultural reasons. ${ }^{18}$

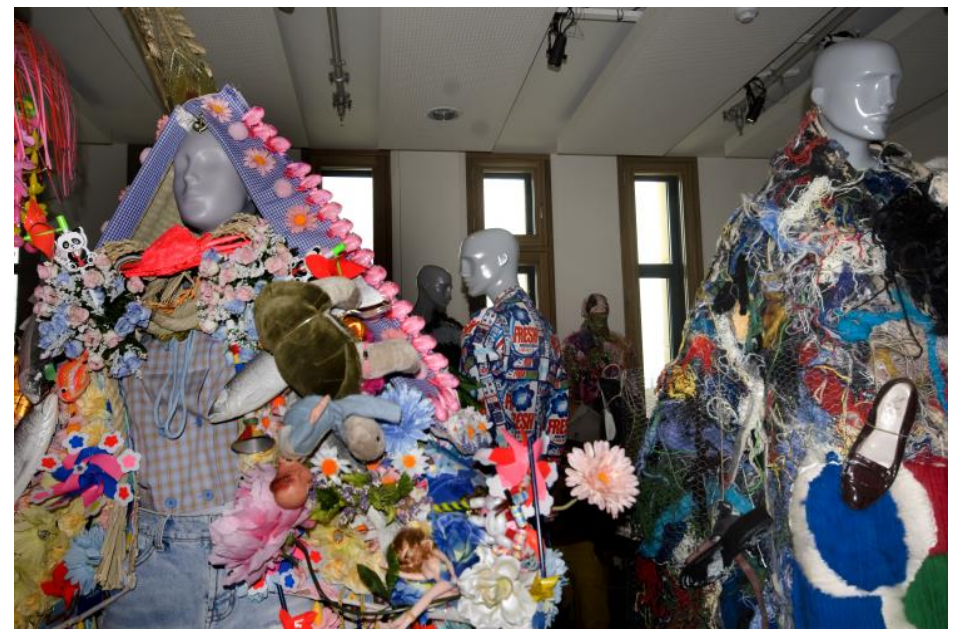

Arnhem Fashion Mode Biennale, 2013. Photo: Gerdien Mogendorf, Gelders Archief.

18 Masterplan Mode \& Vormgeving 2011-2014. 'Bloeicultuur, groeieconomie'. Arnhem: Provincie Gelderland, Gemeente Arnhem, ArtEZ, 2010. 
The relationship between Arnhem and fashion dates back to 1953, when an institute for fashion design was established there. ${ }^{19}$ Since 2005 the city has promoted itself as Arnhem: City of Fashion. In that year the Arnhem Fashion Mode Biennale was organized for the first time, to be repeated every second year until 2013. ${ }^{20}$ This biennial showed the current state of fashion in shows, workshops, and exhibitions. The Arnhem Museum for Modern Art was a partner for the exhibitions. Supported by the city, part of the old district of Klarendal was revived after 2008 as a real fashion quarter, inhabited by several young designers. ${ }^{21}$ The hotel 'Modez' opened its doors in 2012 in this quarter. ${ }^{22}$ The interior of each hotel room was designed by fashion designers who had graduated in Arnhem under the supervision of designer Piet Paris as the art director. Each room tells the story of a different aspect of fashion. So, with the support of municipal and provincial policy and several initiatives in the city, the climate in Arnhem was very much in favor of the Modekern initiative.

When the Modekern was created, there were no real comparable initiatives that could be used as examples. The Victoria and Albert Museum in London has its Archives of Art and Design, ${ }^{23}$ and the Fashion Institute of Technology (FIT) in New York has collections that include fashion archives. ${ }^{24}$ However, in both cases, the acquisition of fashion archives is not related to the importance of the archives per se but because they are related respectively to the collections and to the curriculum offered on fashion. The creation of the MoMu in Antwerp is the closest example to the Modekern

19 See for the history of the institute: EDELKOORT, Lidewij, GODEFROOIJ, Peter and KURSTJENS, Sjoerd, Academie Arnhem 50 jaar in Mode. Arnhem: ArtEZ, 2004.

20 AKKERMANS, H.J.M., WIJN, C.H. and GROOT, W.J.C., Evaluatie van de Arnhem Mode Biënnale. S.1.: BMC, 2011 (retrieved 17/02/2017). Not continued after 2013 (decision of the municipality of Arnhem, see: https://arnhem.notudoc.nl/cgibin/showdoc.cgi/action=view/id=854313/.pdf).

21 SCHEELE, Jorim, Haute Couture in a working class quarter. The way inhabitants and newcomers experience gentrification in their neighbourhood. Graduate Research. Nijmegen: Radboud University, 2011.

22 VAN DER VOET, Hanka, Piet Paris. Arnhem: ArtEZ Press, 2013, pp. 112-119.

23 www.vam.ac.uk/content/articles/a/archive-of-art-and-design (retrieved 17/02/2017).

24 https://www.fitnyc.edu/about/index.php (retrieved 17/02/2017). 
initiative. ${ }^{25}$ This institute is not only a museum but also an archive. Moreover, because it houses the Flanders Fashion Institute, training is possible in conjunction with the collection. However, the MoMu is what the Modekern does not want to be: an institute with all functions in one. The Modekern is and will be a networked organization.

One of the first actions of the Modekern was to formulate an acquisition profile. It was decided to focus on the archives of fashion designers who have their own original style and profile in which the element of design and of conceptual thinking is important. The first priority is given to the designers who are related to Arnhem or broader, the province of Gelderland where Arnhem is situated. Subsequently, attention is paid to other Dutch designers and to Dutch stylists who designed fashion licensed by Paris' fashion houses. The archives of fashion illustrators and of organizations and institutes that document the development of the Dutch fashion design are welcomed as well. The same applies to books and documentation on fashion. The acquisition of fashion archives includes not only the records that document the creation process but also those that document the business of the fashion designer.

Formally the Modekern itself does not acquire archives, but the Gelders Archives does, in the context of the Modekern. The first archives of importance that the Gelders Archives obtained were the ones of Koos van den Akker (1939-2015), which arrived from New York in 2013. The Dutchman Van den Akker lived and worked in New York on Madison Avenue. Among his clients were Elizabeth Taylor, Stevie Wonder, Brooke Shields, Julie and Harry Belafonte, Cher and Glenn Close. ${ }^{26} \mathrm{He}$ is most famous for his sweaters, worn by Bill Cosby on his shows. This archives consists of 8 linear meters of records, documentation and photos. Koos van den Akker donated his archives to the Gelders Archives to be sure that they would be taken care of after his death. The documents have been arranged and described. ${ }^{27}$

25 www.fashioninantwerp.be/momu (retrieved 17/02/2017).

26 VAN DER VOET, Hanka, Koos. Arnhem: ArtEZ Press, 2016.

27 For the online finding aids see: www.geldersarchief.nl, archives nr. 3287 (retrieved 17/02/2017). 
Another acquisition concerns the archives of Piet Paris (1962, pseudonym of Pieter 't Hoen), transferred to the Gelders Archives in 2016. Piet Paris graduated from the Arnhem Fashion Institute. Although trained as a fashion designer, he evolved into a fashion illustrator and currently his sketches are found in fashion magazines like Vogue. He also illustrated the advertising campaigns for Saks Fifth Avenue in New York. ${ }^{28}$ Already in 2013 the Arnhem Museum of Modern Art hosted the exhibition 'Piet Paris's Chambers: The Craft of Fashion Illustration' as their contribution to the Modekern. ${ }^{29}$ The exhibition was designed by Piet Paris himself.

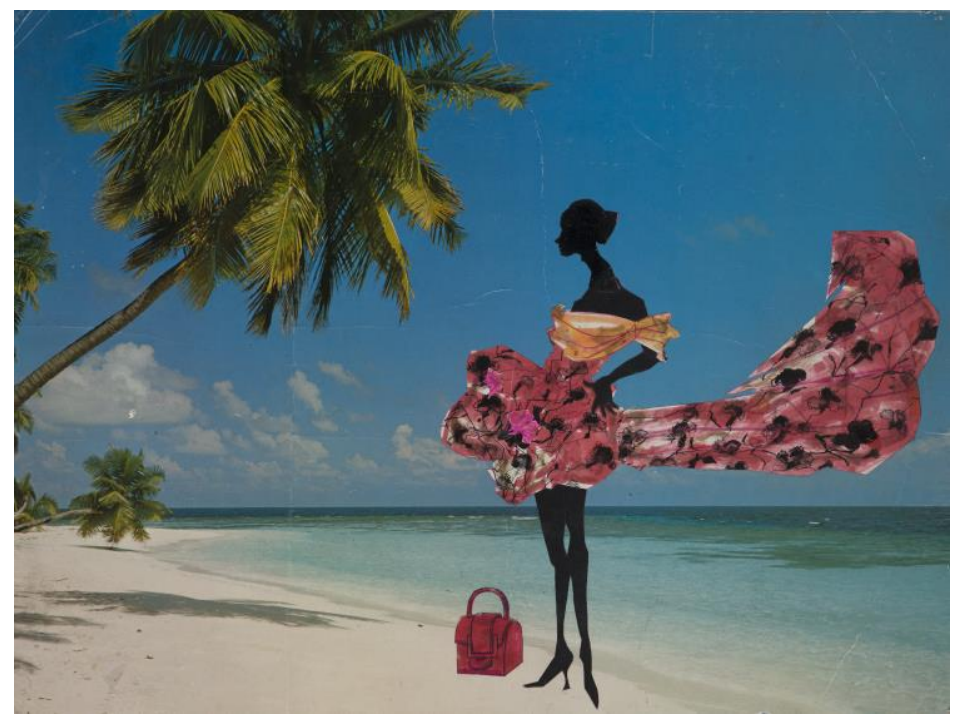

Piet Paris, ‘Cristian Lacroix on the beach’, 1988. Gelders Archief.

Fashion magazines have also been acquired. In 2013, all 40 editions of the Dutch fashion magazine Dutch were obtained. This magazine was published from 1994 to 2002. It first appeared

28 VAN DER VOET, Hanka, Piet Paris.

29 http://www.modekern.nl/site/en/activiteit/tentoonstelling_de_kamers_van_piet_paris/ (retrieved 17/02/2017). 
quarterly and later bimonthly. Led by publisher Sandor Lubbe and fashion editor Matthias Vriens, the magazine grew into a leading international fashion magazine that served as a model for many subsequent independent fashion publications. It launched the careers of photographers such as Philippe Cometti and Matthias Vriens. ${ }^{30}$

Dutch was used for an exhibition called 'Everything but Clothes' that took place in 2015 in the Arnhem Museum, the new name of the Arnhem Museum of Modern Art. ${ }^{31}$ The subject of the exhibition were internationally renowned Dutch (fashion) magazines like Avenue, Dutch, Re-Magazine, BLVD, BLEND, Glamcult, BUTT/KUTT, The Gentlewoman and Fantastic Man. They acted, or still act as a breeding ground and platform for Dutch photographic talent and stylists. The Gelders Archives is planning to acquire those magazines as well.

Currently the Gelders Archives is in the process of acquiring the archives of the international art duo Ravage, consisting of Clemens Rameckers (1949) and Arnold van Geuns (1949), ${ }^{32}$ who both graduated in Arnhem. They are well-known in the world of fashion and design. In 1992 they received the Grand Seigneur, the most important prize for fashion in The Netherlands. ${ }^{33}$ The acquisition will be preceded by an exhibition in the Arnhem Museum.

The Gelders Archives would also like to acquire the archives of Spijkers \& Spijkers. The two sisters Spijkers received their master degrees from the Arnhem Fashion Institute in 2000. In that same year, they presented their graduation collection 'Girlfriend' to the international fashion press in Paris. Next year they set up their label Spijkers \& Spijkers and in 2006 they held their first show in London. ${ }^{34}$ The acquisition of these archives could not be completed because the Spijkers prefer to keep the garments and the archives

30 www.modekern.nl/site/nl/activiteit/modekern_verwerft_dutch_magazine (retrieved 17/02/2017).

31 http://www.modekern.nl/site/nl/activiteit/alles_behalve_kleren (retrieved 17/02/17).

32 EDELKOORT, Lidewij and SILLEVIS, John, Ravage: fascination: fetishism in fashion. Arnhem: Modebiënnale Arnhem, 2013.

33 'Modeprijs 'Grand Seigneur' naar Ravage-duo'. Leidsch Dagblad, 29 June 1992, p. 21 (= http://leiden.courant.nu/issue/LD/1992-08-31/edition/0/page/21; retrieved 17/02/17).

34 TEUNISSEN, José and VAN DER VOET, Hanka, Spijkers en Spijkers (Zwolle: d'jonge Hond, 2012). 
together. That would mean a transfer of the archives to the Gelders Archives and of the garments to the Arnhem Museum. Currently, that is impossible for the museum because of lack of storage capacity.

In 2014 the Modekern organized a conference on fashion heritage in the digital age. This event was a project of the Modekern and the Nieuwe Instituut, the national institute for architecture, design and e-culture. The availability in digital form of vast quantities of fashion heritage (dress collections, archives of designers, textile archives, etc.) is drastically changing fashion research today. During the conference attention was given to questions such as: What does this mean for designers as makers and intellectual owners of their creations? What kinds of new possibilities does the new scenario present? What new tools are available to people doing classic fashion research?

In the context of the Modekern, the ArtEZ has produced three monographs: on Piet Paris, Spijkers \& Spijkers and Koos van den Akker and the book Everything but clothes, published on the occasion of the eponymous exhibition. ${ }^{35}$ This reflects the order in which Modekern prefers to work in future: first an acquisition of the archives of a stylist by the Gelders Archives, subsequently an exhibition organized by the Museum and finally a monograph published by the ArtEZ.

The Modekern has a website www.modekern.nl not only to promote its activities but also to offer an online course on fashion design for secondary school pupils. The nucleus of the website is a database with approximately 60 items on various aspects of fashion and its history. The study material sheds light on various aspects of fashion - art, identity, sustainability, economics - and the work of internationally relevant Dutch designers. In partnership with an education institute, a practical program has been created that's usable at different educational levels and of interest to boys as well as girls. The course materials are freely available at the website and easy to use in the classroom.

35 TEUNISSEN, José, Spijkers en Spijkers; VAN DER VOET, Piet Paris, VAN DER VOET, Hanka, Koos, LAMOREE, Jhim, TEUNISSEN, José and VAN DER VOET, Hanka (eds.), Everything but clothes. Fashion, Photography, Magazines. Arnhem/Houten: ArtEZ Press/Terra Lannoo, 2015. 
The website is also meant to present the fashion archives that are acquired. This will be achieved through links to the finding aids on the Gelders Archives website. All the Gelders Archives' finding aids are also accessible on the Archives Portal Europe. ${ }^{36}$ This portal is the initiative of the national archives in the countries of the European Union and is financed by the European Commission. It aims to provide access to the finding aids of all archival institutions in these countries. In the near future, the archives portal will function as an archives aggregator for Europeana, the European heritage portal for digitized items. An important condition for participating in this heritage portal is the digitization of at least part of the documents that are made accessible through the finding aids. Taking part in Europeana will mean that the fashion archives of the Modekern will be present in the Europeana Fashion Portal, which 'aims to act as a point of reference for fashion institutions in Europe and worldwide'. ${ }^{37}$

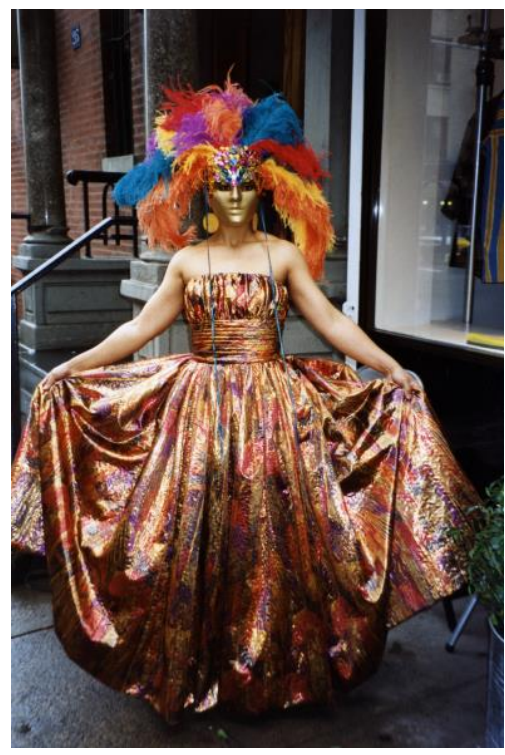

Model dressed in a creation by Koos van den Akker in front of his boutique at Madison Square, New York, 1999. Gelders Archief. 
Began in 2011, the Modekern has achieved several successes so far: the archives of Koos van den Akker and Piet Paris were acquired, two exhibitions were organized, three monographs were published and a well-attended conference was organized. Nevertheless, the development of the Modekern has not proceeded smoothly in all respects. The acquisition of archives is not a simple process. The designers are interested in the Modekern and intend to transfer their archives to the Gelders Archives, but once an archivist knocks at their door they hesitate for several reasons. They are afraid that other designers will steal their ideas; they are worried that their copyright will not always be respected; they are concerned that photographers of their garments will cause problems because they still own the copyright on these photos and they are uncertain about transferring the archives they perhaps need for their work in future. Some designers don't want to break the relationship between their archives and the garments, but currently the Modekern does not have the possibility to store both. Only Koos van den Akker was willing to donate his archives without any condition. For him the situation was different: at the end of his career he was pleased to know that his archives found a good and final place where they will be kept for future generations.

If anyone want to be successful in acquiring fashion archives in the short-term will be disappointed: archives are used to focus on the long-term. All designers will end their career at some moment; we presumably have to wait for that. In these terms there is a future for the Modekern Fashion Heritage Institute.

RECEBIDO EM: 01/03/2017 APROVADO EM: 10/07/2017 